\title{
PENDAPATAN ASLI DAERAH (PAD): PAJAK DAERAH DAN RETRIBUSI DAERAH DI KABUPATEN BANGGAI LAUT
}

\author{
Syamsul $^{1}$, Irma $^{2}$ \\ ${ }^{1,2}$ Prodi Akuntansi, STIE Panca Bhakti Palu, Jl. DR. Suharso No. 36 A Palu, 94111, Indonesia \\ E-mail : syamsulsyahrir@gmail.com
}

\begin{abstract}
This study aims to determine and analyze the level of effectiveness of revenue, growth, and contribution of the main components of local own income (PAD), namely local taxes and retribution. This research was conducted at the Department of Income Management of Finance and Assets (DPPKA) Banggai Laut County. Descriptive analysis shows the majority of the effectiveness of local taxes and retribution is very high and is included in the very effective criteria. Unfortunately, the growth of these types of local taxes and retribution is still considered unsuccessful. Meanwhile, the level of contribution of the types of local taxes and retribution is classified as very poor. In addition, the analysis also informs that several types of local taxes and retribution are included in the prime qualifications.
\end{abstract}

Keywords: local tax; local retribution; local own income (PAD)

\section{PENDAHULUAN}

Sejak ditetapkannya, Undang-Undang Nomor 28 Tahun 2009 tentang Pajak Daerah dan Retribusi Daerah, sejatinya bertujuan untuk meningkatkan kemampuan keuangan daerah sehingga mereduksi dominasi sumbangan pemerintah pusat dalam membiayai kebutuhan daerah. Lahirnya UU tersebut, juga dapat dimaknai bahwa peluang pemerintah daerah semakin luas untuk mengoptimalkan Pendapatan Asli Daerah (PAD) melalui sumber pajak daerah dan retribusi daerah. Mengingat, pajak daerah dan retribusi daerah diyakini sebagai komponen utama PAD (Nopyandri, 2015) yang akan memberikan sumbangsih terbesar terhadap penerimaan PAD apabila dikelola dengan baik (Mardiasmo, 2004:183).

Sayangnya, sampai saat ini hakikat dari UU tersebut belum tercapai sepenuhnya, kondisi ini terlihat dari masih rendahnya kontribusi PAD terhadap pendapatan daerah (Gunawan, 2018; Kamaroellah, 2017; Mizkan et al., 2015; Ngangi et al., 2018; Rosa et al., 2020; Sambodo dan Putri, 2020; Syamsul, 2020, 2019). Selain itu, belum optimalnya daerah dalam menerapkan regulasi tersebut, lebih khusus juga tercermin dari rendahnya tingkat kontribusi pajak daerah dan retribusi daerah terhadap PAD (Sartika et al., 2019; Syamsul, 2019; Utami dan Ningsih, 2018). Singkatnya, PAD masih didominasi oleh kontribusi dari dua komponen lain yaitu lain-lain PAD yang sah dan hasil pengelolaan kekayaan daerah yang dipisahkan. Oleh karena itu, perlu ditelusuri tingkat efektivitas penerimaan, perkembangan, dan kontribusi dari komponen $\mathrm{PAD}$, utamanya yang berasal dari pajak daerah dan retribusi daerah.

Pemerintah Kabupaten Banggai Laut adalah daerah otonom yang terletak di wilayah Provinsi Sulawesi Tengah, telah berusaha memaksimalkan pendapatan daerahnya yang bersumber dari PAD. Tabel 1 menunjukkan bahwa rerata persentase realisasi PAD Kabupaten Banggai Laut selama tahun 2016-2019 sebesar 105,55 persen. Lebih rinci, realisasi PAD pada tahun 2016 sebesar 114,89 persen, tahun 2017 sebesar 108,97, tahun 2019 sebesar 100 persen, dan tahun 2019 sebesar 98,34 persen. Kemudian, rerata perkembangan PAD selama empat tahun adalah sebesar 20,16 persen, perkembangan pada tahun 2017 sebesar 29,67 persen, tahun 2018 sebesar -5,48 persen dan tahun 2019 sebesar 36,30 persen. Artinya, tingkat perkembangan PAD Kabupaten Banggai Laut masih sangat fluktuatif. 
Tabel 1. Persentase Realisasi Pendapatan Asli Daerah (PAD) Kabupaten Banggai Laut Tahun 2016-2019

\begin{tabular}{crrrrrrrr}
\hline Tahun & \multicolumn{3}{c}{ Realisasi } & \multicolumn{1}{c}{$\boldsymbol{g}$ PAD $\boldsymbol{g}$ PD } & $\boldsymbol{g}$ RD & \multirow{2}{*}{ w PD } & \multirow{2}{*}{$\boldsymbol{w}$ RD } \\
\hline 2016 & 114.89 & 111.90 & \multicolumn{1}{c}{147.23} & & & & 24.67 & 41.50 \\
2017 & 108.97 & 120.73 & 93.85 & 29.67 & 38.56 & 5.44 & 26.36 & 33.75 \\
2018 & 100.00 & 121.10 & 251.53 & -5.48 & 2.28 & 12.81 & 28.53 & 40.28 \\
2019 & 98.34 & 93.98 & 90.11 & 36.30 & 8.85 & 47.53 & 22.79 & 43.60 \\
Rerata & 105.55 & 111.93 & 145.68 & 20.16 & 16.56 & 21.93 & 25.59 & 39.78 \\
\hline
\end{tabular}

Sumber: Data diolah dari DPPKA Kabupaten Banggai Laut, 2020

Lebih dari itu, Tabel 1 juga menunjukkan bahwa rerata realisasi pajak daerah Kabupaten Banggai Laut selama tahun 2016-2019 sebesar 111,93 persen. Kemudian dari segi tingkat perkembangan dan kontribusinya terhadap PAD, yaitu pajak daerah memiliki rerata perkembangan sebesar 15,56 persen dan tingkat kontribusinya sebesar 25,59 persen. Sementara itu, rerata realisasi retribusi daerah sebesar 145,68 persen dengan tingkat perkembangan realisasi retribusi daerah selama tahun 2016-2019 sebesar 16,56 persen, dan rerata tingkat kontribusinya terhadap PAD sebesar 39,78 persen. Maknanya, tingkat perkembangan dan kontribusi pajak daerah lebih rendah dibanding retribusi daerah, serta perkembangan dan kontribusi kedua komponen PAD tersebut masih sangat fluktuatif.

Melihat fenomena di atas, penelitian ini hadir dan bertujuan untuk menganalisis dan mengetahui lebih dalam terkait kondisi efektivitas penerimaan, perkembangan, dan kontribusi dari setiap jenis pajak daerah maupun retribusi daerah di Kabupaten Banggai Laut. Kemudian, mengetahui kriteria kedua komponen PAD tersebut berdasarkan rasio efektivitas penerimaan, perkembangan, dan kontribusinya. Terakhir, mengungkap klasifikasi dari setiap jenis pajak daerah dan retribusi daerah tersebut berdasarkan analisis overlay. Oleh karena itu, penelitian ini penting dalam memberikan informasi tambahan kepada perumus kebijakan terkait kondisi terkini PAD yang bersumber dari pajak daerah dan retribusi daerah di Kabupaten Banggai Laut. Sebab dengan mengetahui kondisi terkini dari kedua komponen PAD tersebut, diharapkan kebijakan yang diambil oleh para pengambil keputusan dalam rangka memaksimalkan penerimaan PAD dari kedua komponen tersebut menjadi lebih tepat.

\section{TINJAUAN PUSTAKA}

\subsection{Pendapatan Asli Daerah (PAD)}

Menurut Undang-Undang Nomor 33 Tahun 2004 tentang Perimbangan Keuangan antara Pemerintah Pusat dan Pemerintah Daerah, dijelaskan bahwa Pendapatan Asli Daerah (PAD) adalah pendapatan yang diperoleh daerah yang dipungut berdasarkan peraturan daerah sesuai dengan peraturan perundang-undangan. PAD dikelompokkan menurut jenis pendapatan yaitu pajak daerah, retribusi daerah, hasil pengelolaan kekayaan milik daerah yang dipisahkan, dan lain-lain pendapatan asli daerah yang sah.

\subsection{Pajak Daerah}

Menurut Undang-Undang Nomor 28 Tahun 2009 tentang Pajak Daerah dan Retribusi Daerah, pajak daerah adalah kontribusi wajib kepada daerah yang terutang oleh orang pribadi atau badan yang bersifat memaksa berdasarkan undang-undang dengan tidak mendapatkan imbalan secara langsung dan digunakan untuk keperluan daerah bagi sebesar-besarnya kemakmuran rakyat. Jenis pajak yang dipungut oleh pemerintah daerah (kabupaten/kota) adalah pajak hotel, restoran, hiburan, reklame, penerangan jalan, pengambilan bahan galian golongan $\mathrm{C}$, lingkungan, mineral bukan logam dan bantuan, parkir, burung walet, bumi dan bangunan pedesaan dan perkotaan, dan BPHTB. 
Penelitian Sucanti et al. (2017) di Kabupaten Gianyar tahun 2012-2016 menjelaskan bahwa tingkat realisasi pajak daerah terbilang sangat efektif dan kontribusi pajak daerah terhadap PAD di Kabupaten Gianyar dinyatakan sangat baik. Hasil penelitian Utami dan Ningsih (2018) pada kabupaten/kota di Provinsi Aceh tahun 2011-2015 menunjukkan bahwa penerimaan pajak daerah dapat dikategorikan sangat efektif, dan kontribusi pajak daerah terhadap PAD diproyeksikan berada pada level sedang. Selain itu, temuan penelitian mereka juga menyampaikan bahwa realisasi pajak daerah dan kontribusinya terhadap PAD tidak meningkat secara signifikan. Kemudian, Tamburaka et al. (2018) menginformasikan bahwa realisasi pajak daerah Kabupaten Konawe pada tahun 2013 sebesar 118 persen, tahun 2014, dan 2015 sebesar 109 persen, dengan rerata penerimaan selama tahun 2013-2015 sebesar 112 persen. Tamburaka et al. (2018) menyimpulkan bahwa realisasi pajak daerah terbilang sudah sangat efektif. Sedangkan, kontribusi pajak daerah terhadap PAD rerata sebesar 25 persen, tergolong cukup berkontribusi. Syamsul (2019) menunjukkan bahwa rerata tingkat pertumbuhan dan kontribusi pajak daerah Pemerintah Kabupaten Parigi Moutong selama tahun 2013-2017 masih terbilang rendah (berkembang). Sartika et al. (2019) yang menganalisis tingkat efektivitas, pertumbuhan, dan kontribusi pajak daerah kabupaten/kota di Sumatera Barat tahun 2012 sampai 2016. Hasil analisis mengindikasikan bahwa dari sisi realisasi pajak daerah termasuk pada kriteria efektif. Dari perhitungan pertumbuhan pajak daerah tergolong tidak berhasil. Sedangkan, dari kontribusinya terhadap PAD tergolong pada kriteria cukup baik. Berdasarkan temuan dari beberapa penelitian tersebut, dapat dikatakan bahwa tingkat realisasi pajak daerah rerata sudah cukup efektif, tingkat kontribusinya terbilang cukup baik, dan tingkat perkembangannya juga sudah cukup berhasil.

\subsection{Retribusi Daerah}

Undang-Undang Nomor 28 Tahun 2009 menjelaskan bahwa retribusi daerah adalah pungutan daerah sebagai pembayaran atas jasa dan atau pemberian izin tertentu yang khusus disediakan dan/atau diberikan oleh pemerintah daerah untuk kepentingan orang pribadi atau badan. Lebih lanjut berdasarkan Undang-Undang tersebut retribusi yang dipungut atas jasa umum adalah pengutan daerah sebagai pembayaran atas pelayanan yang disediakan atau diberikan pemerintah daerah untuk tujuan kepentingan dan kemanfaatan umum serta dapat dinikmati oleh orang pribadi atau badan. Tetapi dapat tidak dipungut apabila potensi penerimannya kecil dan/atau atas kebijakan nasional/daerah untuk memberikan pelayanan tersebut secara gratis. Jenis retribusi jasa umum antara lain berupa: retribusi pelayanan kesehatan, retribusi pelayanan persampahan/kebersihan, retribusi penggantian biaya cetak kartu tanda penduduk dan akta catatan sipil, retribusi pelayanan pemakaman dan pengabuan mayat, retribusi pelayanan parkir di tepi jalan umum, retribusi pelayanan pasar, retribusi pengujian kendaraan bermotor, retribusi pemeriksaan alat pemadam kebakaran, retribusi penggantian biaya cetak peta, retribusi penyediaan/atau penyedotan kakus, retribusi pengelohan limbah cair, retribusi pelayanan tera/tera ulang, retribusi pelayanan pendidikan; dan retribusi pengendalian menara telekomunikasi.

Selanjutnya, retribusi atas jasa usaha adalah pungutan daerah sebagai pembayaran atas pelayanan yang disediakan oleh pemerintah daerah dengan menganut prinsip komersial yang meliputi pelayanan dengan menggunakan/memanfaatkan kekayaan daerah yang belum dimanfaatkan secara optimal dan/atau pelayanan oleh pemerintah daerah sepanjang belum disediakan secara memadai oleh pihak swasta. Jenis retribusi yang dipungut atas jasa usaha ini antara lain; retribusi pemakaian kekayaan daerah, retribusi pasar grosir dan/atau pertokoan, retribusi tempat pelelangan, retribusi terminal, retribusi tempat khusus parkir, retribusi tempat penginapan/pesangrahan/villa, retribusi rumah potong hewan, retribusi pelayanan kepelabuhanan, retribusi tempat rekreasi dan olahraga, retribusi penyeberangan di air dan retribusi penjualan produksi usaha daerah (Undang-Undang Nomor 28 Tahun 2009). Kemudian, UU tersebut juga menyebutkan bahwa retribusi atas perizinan tertentu adalah 
pungutan daerah atas pembayaran pelayanan perizinan tertentu oleh pemerintah daerah kepada orang pribadi atau badan yang dimaksudkan untuk pengaturan dan pengawasan atas kegiatan pemanfaatan ruang, penggunaan sumber daya alam, barang, prasarana, sarana, atau fasilitas tertentu guna melindungi kepentingan umum dan menjaga kelestarian lingkungan. Jenis retribusi perizinan tertentu adalah; retribusi izin mendirikan bangunan, retribusi izin tempat penjualan minuman beralkohol, retribusi izin gangguan, retribusi izin trayek; dan retribusi izin usaha perikanan.

Sartika et al. (2019) yang menganalisis tingkat efektivitas, pertumbuhan, dan kontribusi retribusi daerah kabupaten/kota di Sumatera Barat dengan data yang diolah adalah data realisasi anggaran tahun 2012 sampai 2016 menemukan bahwa realisasi retribusi daerah juga termasuk pada kriteria efektif. Tingkat pertumbuhan retribusi daerah termasuk dalam kategori tidak berhasil, dan dari kontribusinya terhadap PAD termasuk pada kriteria kurang baik. Penelitian Utami dan Ningsih (2018) pada kabupaten/kota di Provinsi Aceh tahun 20112015 menunjukkan bahwa rerata realisasi retribusi daerah dikategorikan kurang efektif. Kemudian, kontribusi retribusi daerah terhadap PAD diproyeksikan juga berada pada level sedang. Mereka juga menyampaikan bahwa penerimaan retribusi daerah serta kontribusinya terhadap PAD tidak terdapat peningkatan secara signifikan. Hasil Sucanti et al. (2017) menjelaskan bahwa realisasi retribusi daerah di Kabupaten Gianyar dinyatakan sangat efektif. Sementara kontribusi retribusi daerah terhadap PAD di Kabupaten Gianyar dinyatakan sangat kurang. Penelitian Syamsul (2019) yang dilakukan di Badan Pengelola Keuangan dan Aset Daerah (BPKAD) Pemerintah Kabupaten Parigi Moutong selama tahun 2013-2017 menunjukkan bahwa rerata tingkat pertumbuhan dan kontribusi retribusi daerah terhadap PAD masih sedikit (berkembang). Temuan penelitian terdahu secara umum menunjukkan bahwa rerata realisasi retribusi daerah sudah cukup efektif, tingkat perkermbangannya juga sudah cukup berhasil, meskipun tingkat kontribusinya terhadap PAD masih belum termasuk dalam ketogori cukup baik.

\section{METODE PENELITIAN}

\subsection{Jenis dan sumber data}

Penelitian ini adalah penelitian deskriptif. Jenis data yang digunakan dalam penelitian adalah data sekunder. Data sekunder penelitian ini berupa data Realisasi PAD Kabupaten Banggai Laut Periode tahun 2016-2019. Sumber data penelitian ini adalah sumber data sekunder. Data sekunder penelitian ini berupa data realisasi PAD yang diperoleh dari Dinas Pendapatan Pengelolaan Keuangan dan Aset (DPPKA) Kabupaten Banggai Laut. Teknik pengumpulan data dalam penelitian ini menggunakan teknik pengumpulan data dokumentasi. Data dokumentasi penelitian ini berupa peraturan, kebijakan dan laporan berkenaan dengan realisasi PAD periode tahun 2016-2019.

\subsection{Objek penelitian}

Objek Penelitian ini adalah Pendapatan Asli Daerah (PAD), pajak daerah, dan retribusi daerah pada Dinas Pendapatan Pengelolaan Keuangan dan Asset (DPPKA) Pemerintah Kabupaten Banggai Laut, Provinsi Sulawesi Tengah.

\subsection{Metode analisis}

Data pada penelitian ini dianalisis dengan melakukan analisis rasio efektifitas, rasio perkembangan (pertumbuhan), dan rasio kontribusi. Analisis rasio efektivitas bertujuan untuk mengetahui seberapa besar kemampuan pemerintah daerah dalam merealisasikan PAD maupun komponen-komponen PAD berdasarkan target yang telah ditetapkan dalam suatu periode, dengan menggunakan rumus sebagai berikut:

Keterangan:

$$
\triangle \mathrm{ERi}=\frac{X r t}{X t t} \times 100 \%
$$


$\triangle \mathrm{ER}_{\mathrm{i}}:$ Rasio efektifitas PAD/komponen PAD

$\mathrm{X}_{\mathrm{rt}} \quad$ : Realisasi PAD/komponen PAD tahun ke $\mathrm{t}$

$\mathrm{X}_{\mathrm{tt}} \quad$ : Realisasi PAD/komponen PAD tahun ke $\mathrm{t}$

Analisis rasio perkembangan (pertumbuhan), digunakan untuk mengetahui tingkat pertumbuhan PAD maupun komponen-komponen PAD dalam suatu periode, formulanya adalah sebagai berikut:

Keterangan:

$$
\triangle \mathrm{Xi}=\frac{X i t-X i t(t-1)}{X i t(t-1)} \times 100 \%
$$

$\triangle \mathrm{X}_{\mathrm{i}} \quad$ : Rasio perkembangan PAD/komponen PAD

$\mathrm{X}_{\text {it }} \quad$ : Realisasi PAD/komponen PAD tahun ke $\mathrm{t}$

$\mathrm{X}_{\text {it (t-1) }}$ : Realisasi PAD/komponen PAD tahun ke t-1

Sementara itu, analisis rasio kontribusi dilakukan untuk mengetahui kontribusi PAD maupun komponen-komponen PAD dalam suatu periode, rumusnya sebagai berikut:

$$
\begin{array}{ll}
\qquad \mathrm{Xi}=\frac{\mathrm{Xi}}{\mathrm{X}} \times 100 \% \\
\triangle \mathrm{X}_{\mathrm{i}} & : \text { Rasio kontribusi PAD/komponen PAD } \\
\mathrm{X}_{\mathrm{i}} & : \text { Realisasi PAD/komponen PAD } \\
\mathrm{X} & : \text { Total PAD/komponen PAD }
\end{array}
$$

Tabel 2. Kriteria Efektivitas, Perkembangan, dan Kontribusi Pajak Daerah dan Retribusi Daerah

\begin{tabular}{cccccc}
\hline $\begin{array}{c}\text { Tingkat } \\
\text { Efektifitas }\end{array}$ & Kriteria & $\begin{array}{c}\text { Tingkat } \\
\text { Perkembangan }\end{array}$ & Kriteria & $\begin{array}{c}\text { Derajat } \\
\text { Kontribusi }\end{array}$ & Kriteria \\
\hline$>100 \%$ & Sangat Efektif & $85 \%-100 \%$ & Sangat Berhasil & $>50 \%$ & Sangat Baik \\
$90 \%-100 \%$ & Efektif & $70 \%-85 \%$ & Berhasil & $40 \%-50 \%$ & Baik \\
$80 \%-90 \%$ & Cukup Efektif & $55 \%-70 \%$ & Cukup Berhasil & $30 \%-40 \%$ & Sedang \\
$60 \%-80 \%$ & Kurang Efektif & $30 \%-55 \%$ & Kurang Berhasil & $20 \%-30 \%$ & Cukup Baik \\
$<60 \%$ & Tidak Efektif & $<30 \%$ & Tidak Berhasil & $10 \%-20 \%$ & Kurang Baik \\
& & & & $<10 \%$ & Sangat Kurang Baik \\
\hline
\end{tabular}

Sumber: Halim (2007:291) dalam Sartika et al. (2019) dan Syamsul (2020, 2019)

Selanjutnya, setelah diketahui rasio efektifitas, perkembangan, dan kontribusi PAD maupun komposisi PAD, kemudian ditentukan nilai rerata PAD maupun komposisinya. Setelah itu, dilakukan pembahasan berdasarkan kriteria yang telah ditetapkan pada Tabel 2 . Terahir, dilakukan analisis overlay. Analisis ini bertujuan untuk menggambarkan deskripsi kegiatan jenis pajak daerah/retribusi daerah potensial yang didasarkan pada kriteria pertumbuhan dan kriteria kontribusi (Kurniawan, 2019). Oleh karena itu, terlebih dahulu dilakukan identifikasi atau klasifikasi kondisi didasarkan pada kontribusi dan perkembangan setiap jenis pajak daerah/retribusi daerah. Proses identifikasi dilakukan dengan cara matrik antara kontribusi komposisi atau komponen penerimaan dan pertumbuhan (perkembangan) penerimaan (lihat, Tabel 3). Kemudian dikelompokkan ke dalam empat kondisi, yaitu sebagai berikut: (1) Prima, jika pajak daerah/retribusi daerah memberikan kontribusi dan pertumbuhan sama dengan atau lebih dari 1 persen; (2) Potensial, jika pajak daerah/retribusi daerah memberikan kontribusi sama dengan atau lebih dari 1 persen sedangkan pertumbuhan kurang dari 1 persen; (3) Berkembang, jika pajak daerah/retribusi daerah memberikan kontribusi kurang dari 1 persen sedangkan pertumbuhan sama dengan atau lebih dari 1 persen; dan (4) Terbelakang, jika pajak daerah/retribusi daerah memberikan kontribusi dan pertumbuhan kurang dari 1 persen. 
Tabel 3. Matrik Komposisi Kontribusi dan Pertumbuhan Komponen Pendapatan Asli Daerah (PAD)

\begin{tabular}{|c|c|c|}
\hline Kontribusi & & \\
\hline Pertumbuhan & wXi $\geq 1$ (tinggi) & wXi $<1$ (rendah) \\
\hline $\mathrm{gXi} \geq 1$ (tinggi) & & \\
\hline $\mathrm{gXi}<1$ (rendah) & Prima & Berkembang \\
\hline
\end{tabular}

Sumber: Jaya (1996) diikuti oleh Kurniawan (2019) dan Syamsul (2019)

\section{HASIL PENELITIAN DAN PEMBAHASAN}

\subsection{Hasil penelitian}

Efektivitas penerimaan, perkembangan, dan kontribusi jenis pajak daerah. Pajak daerah adalah semua penerimaan daerah yang berasal dari kontribusi wajib orang atau badan yang berkedudukan di daerah tersebut.Tabel 4 menginformasikan tentang persentase realisasi jenis pajak daerah Kabupaten Banggai Laut tahun 2017-2019. Dalam tabel itu terlihat bahwa rerata efektivitas penerimaan jenis pajak daerah sebesar 112,77 persen. Kemudian, rerara efektivitas penerimaan jenis pajak daerah kurang dari 100 persen, yaitu hanya pajak hiburan sebesar 86,60 persen dan pajak papan reklame/billboard/seng sebesar 80,64 persen, rerata penerimaan jenis pajak daerah tertinggi yaitu bea perolehan hak atas tanah dan bangunan perdesaan dan perkotaan sebesar 164,08 persen dan disusul pajak hotel sebesar 131,42 persen. Selain itu, pada tahun 2017 efektivitas penerimaan jenis pajak daerah tertinggi yaitu pajak hiburan sebesar 170,45 persen dan terendah pajak papan reklame/billboard/seng sebesar 78,25 persen. Pada tahun 2018 efektivitas realisasi jenis pajak daerah tertinggi yaitu bea perolehan hak atas tanah dan bangunan perdesaan dan perkotaan sebesar 180,08 persen dan terendah pajak hiburan sebesar 73,33 persen, dan tahun 2019 tertinggi yaitu bea perolehan hak atas tanah dan bangunan perdesaan dan perkotaan sebesar 103,71 persen dan terendah pajak hiburan sebesar 16 persen. Singkatnya, mayoritas realisasi jenis pajak daerah mencapai target yang telah ditetapkan.

Tabel 4. Persentase Efektivitas Penerimaan Jenis Pajak Daerah Kabupaten Banggai Laut Tahun 2017-2019

\begin{tabular}{lrrrr}
\hline \multirow{2}{*}{ Jenis Pajak Dae rah } & \multicolumn{3}{c}{ Tahun } \\
& $\mathbf{2 0 1 7}$ & $\mathbf{2 0 1 8}$ & $\mathbf{2 0 1 9}$ & \multicolumn{1}{c}{ Re rata } \\
\hline Pajak Hotel & 154,33 & 129,21 & 110,71 & 131,42 \\
Pajak Restoran & 106,29 & 139,82 & 106,06 & 117,39 \\
Pajak Hiburan & 170,45 & 73,33 & 16,00 & 86,60 \\
Pajak Papan Reklame/Billboard/ Seng & 78,25 & 100,99 & 62,67 & 80,64 \\
Pajak Penerangan Jalan Rumah Tangga & 115,29 & 125,69 & 111,33 & 117,44 \\
Pajak Galian Batu / Kerikil / Pasir & 141,85 & 114,96 & 45,78 & 100,86 \\
PBB Perdesaan dan Perkotaan & 105,22 & 102,42 & 103,71 & 103,78 \\
Bea Perolehan Hak atas Tanah dan Bangunan & 159,39 & 180,08 & 152,77 & 164,08 \\
$\quad$ Rerata & $\mathbf{1 2 8 , 8 8}$ & $\mathbf{1 2 0 , 8 1}$ & $\mathbf{8 8 , 6 3}$ & $\mathbf{1 1 2 , 7 7}$ \\
\hline
\end{tabular}

Sumber: Data diolah dari DPPKA Kabupaten Banggai Laut, 2020

Selanjutnya, Tabel 5 menampilkan persentase tingkat perkembangan pajak daerah Kabupaten Banggai Laut tahun 2017-2019. Dari tabel itu, dapat diterangkan tingkat 
perkembangan jenis pajak daerah secara rerata adalah sebesar 18,88 persen, rerata tertinggi yaitu bea perolehan hak atas tanah dan bangunan sebesar 77,66 persen dan terendah pajak papan reklame/billboard/seng sebesar $-33,79$ persen. Realisasi perkembangan jenis pajak daerah tahun 2017 , tertinggi yaitu pajak hiburan sebesar 87,5 persen dan terendah pajak papan reklame/billboard/seng sebesar -13,92 persen, tahun 2018 tertinggi bea perolehan hak atas tanah dan bangunan sebesar 67,49 persen dan terendah pajak papan reklame/billboard/seng sebesar -80,53 persen, dan tahun 2019 tertinggi bea perolehan hak atas tanah dan bangunan sebesar 161,03 persen dan pajak hiburan -63,64 persen. Singkatnya, dari tabel tersebut menginformasikan bahwa tingkat perkembangan jenis pajak daerah sebagian besar berada diatas nilai rerata.

Tabel 5. Persentase Tingkat Perkembangan Jenis Pajak Daerah Kabupaten Banggai Laut Tahun 2017-2019

\begin{tabular}{lrrrr}
\hline \multicolumn{1}{c}{ Jenis Pajak Dae rah } & \multicolumn{4}{c}{ Tahun } \\
& $\mathbf{2 0 1 7}$ & $\mathbf{2 0 1 8}$ & $\mathbf{2 0 1 9}$ & \multicolumn{1}{c}{ Re rata } \\
\hline Pajak Hotel & 69,76 & $-3,21$ & 17,81 & 28,12 \\
Pajak Restoran & 16,91 & 33,30 & 0,91 & 17,04 \\
Pajak Hiburan & 87,50 & $-26,67$ & $-63,64$ & $-0,93$ \\
Pajak Papan Reklame/Billboard/ Seng & $-13,92$ & $-80,53$ & $-6,92$ & $-33,79$ \\
Pajak Penerangan Jalan Rumah Tangga & 34,36 & 9,02 & 17,73 & 20,37 \\
Pajak Galian Batu / Kerikil / Pasir & 56,03 & $-12,21$ & $-55,76$ & $-3,98$ \\
PBB Perdesaan dan Perkotaan & 38,44 & $-3,05$ & 104,31 & 46,57 \\
Bea Perolehan Hak atas Tanah dan Bangunan & 4,46 & 67,49 & 161,03 & 77,66 \\
\multicolumn{1}{l}{ Re rata } & $\mathbf{3 6 , 6 9}$ & $\mathbf{- 1 , 9 8}$ & $\mathbf{2 1 , 9 3}$ & $\mathbf{1 8 , 8 8}$ \\
\hline
\end{tabular}

Sumber: Data diolah dari DPPKA Kabupaten Banggai Laut, 2020

Kemudian, Tabel 6 di bawah ini menggabarkan persentase tingkat kontribusi jenis pajak daerah terhadap pajak daerah di Kabupaten Banggai Laut tahun 2017-2019. Pada tabel itu tercatat bahwa tingkat kontribusi jenis pajak daerah sebesar 37,96 yaitu pajak penerangan jalan rumah tangga dan terendah pajak hiburan sebesar 0,01 persen. Tingkat kontribusi jenis pajak daerah untuk tahun 2017, 2018, 2019 tertinggi yaitu pajak penerangan jalan rumah tangga sebesar 35,38 persen, 37,71 persen, dan 40,79 persen dan yaitu pajak hiburan sebesar 0,01 persen tahun 2017, sebesar 0,01 tahun 2018, dan sebesar 0 persen tahun 2019. Melalui tabel itu, secara sederhana dapat diartikan tingkat kontribusi jenis pajak daerah terhadap pajak daerah sebagian besar dibawah angka 30 persen.

Tabel 6. Persentase Tingkat Kontribusi Jenis Pajak Daerah Kabupaten Banggai Laut Tahun 2017-2019

\begin{tabular}{lrrrr}
\hline \multicolumn{1}{c}{ Jenis Pajak Dae rah } & \multicolumn{2}{c}{ Tahun } \\
& $\mathbf{2 0 1 7}$ & $\mathbf{2 0 1 8}$ & $\mathbf{2 0 1 9}$ & Re rata \\
\hline Pajak Hotel & 2,07 & 1,96 & 2,12 & 2,05 \\
Pajak Restoran & 11,10 & 14,47 & 13,41 & 13,00 \\
Pajak Hiburan & 0,01 & 0,01 & 0,00 & 0,01 \\
Pajak Papan Reklame/Billboard/ Seng & 1,01 & 0,19 & 0,16 & 0,45 \\
Pajak Penerangan Jalan Rumah Tangga & 35,38 & 37,71 & 40,79 & 37,96 \\
Pajak Galian Batu / Kerikil / Pasir & 34,34 & 29,47 & 11,98 & 25,26 \\
PBB Perdesaan dan Perkotaan & 14,72 & 13,96 & 26,19 & 18,29 \\
Bea Perolehan Hak atas Tanah dan Bangunan & 1,36 & 2,22 & 5,33 & 2,97 \\
\hline
\end{tabular}

Sumber: Data diolah dari DPPKA Kabupaten Banggai Laut, 2020 
Efektivitas penerimaan, perkembangan, dan kontribusi jenis retribusi daerah. Pada Tabel 7 di bawah ini menampilkan tentang persentase realisasi jenis retribusi daerah Kabupaten Banggai Laut selama tahun 2017-2019. Dalam tabel itu termuat bahwa rerata realisasi kelompok retribusi jasa umum sebesar 139,28 persen, retribusi jasa usaha sebesar 102, 35 persen, dan retribusi perizinan tertentu sebesar 163, 58 persen. Lebih detail, rerata realisasi jenis retribusi jasa umum tertinggi yaitu retribusi pelayanan pasar sebesar 168,49 persen dan terendah retribusi pengujian kendaraan bermotor sebesar 80,67 persen. Pada tahun 2017 realisasi jenis retribusi jasa umum tertinggi yaitu retribusi pelayanan parkir ditepi jalan umum sebesar 203,43 persen dan terendah retribusi pelayanan kesehatan sebesar 87,18 persen, tahun 2018 realisasi jenis retribusi jasa umum tertinggi yaitu retribusi pelayanan pasar sebesar 254,86 persen dan terendah retribusi pelayanan parkir ditepi jalan umum sebesar 102,33 persen, dan tahun 2019 realisasi jenis retribusi jasa umum tertinggi yaitu retribusi pelayanan persampahan sebesar 145,08 persen dan terendah retribusi pengujian kendaraan bermotor sebesar 0 persen. Disisi lain, dari Tabel 7 juga dapat dijelaskan rerata realisasi jenis retribusi jasa usaha tertinggi yaitu retribusi pelayanan jasa kepelabuhanan sebesar 144,76 persen dan terendah retribusi pemakaian kekayaan daerah sebesar 60,73 persen. Selama tahun 2017 realisasi jenis retribusi jasa usaha tertinggi yaitu retribusi pelayanan jasa kepelabuhanan sebesar 143,91 persen dan terendah retribusi terminal sebesar 95 persen, tahun 2018 realisasi jenis retribusi jasa usaha tertinggi yaitu retribusi pelayanan jasa kepelabuhanan sebesar 146,26 persen dan terendah retribusi pemakaian kekayaan daerah sebesar 0 persen, dan tahun 2019 realisasi jenis retribusi jasa usaha tertinggi yaitu retribusi pelayanan jasa kepelabuhanan sebesar 144,1 persen dan terendah retribusi pemakaian kekayaan daerah sebesar 73 persen.

Tabel 7. Persentase Efektivitas Realisasi Jenis Retribusi Daerah Kabupaten Banggai Laut Tahun 2017-2019

\begin{tabular}{lrrrr}
\hline \multicolumn{1}{c}{ Jenis Retribusi Dae rah } & \multicolumn{2}{c}{ Tahun } \\
& $\mathbf{2 0 1 7}$ & $\mathbf{2 0 1 8}$ & $\mathbf{2 0 1 9}$ & \multicolumn{1}{c}{ Re rata } \\
\hline Retribusi Jasa Umum & $\mathbf{8 9 , 0 1}$ & $\mathbf{2 3 9 , 9 8}$ & $\mathbf{8 8 , 8 4}$ & $\mathbf{1 3 9 , 2 8}$ \\
Retribusi Pelayanan Parkir ditepi Jalan Umum & 203,43 & 102,33 & 99,48 & 135,08 \\
Retribusi Pengujian Kendaraan Bermotor & 117,95 & 124,04 & 0,00 & 80,67 \\
Retribusi Pelayanan Persampahan/ Kebersihan & 130,97 & 123,94 & 145,08 & 133,33 \\
Retribusi Pelayanan Pasar & 113,43 & 254,86 & 137,18 & 168,49 \\
Retribusi Pelayanan Kesehatan : & 87,18 & 236,55 & 87,20 & 136,98 \\
Retribusi Jasa Usaha & $\mathbf{1 1 1 , 4 5}$ & $\mathbf{1 0 3 , 7 5}$ & $\mathbf{9 1 , 8 4}$ & $\mathbf{1 0 2 , 3 5}$ \\
Retribusi Pemakaian Kekayaan Daerah & 109,08 & 0,00 & 73,10 & 60,73 \\
Retribusi Terminal & 95,00 & 72,63 & 103,78 & 90,47 \\
Retribusi Pelayanan Jasa Kepelabuhanan & 143,91 & 146,26 & 144,10 & 144,76 \\
Rumah Potong Hewan & 100,00 & 100,10 & 108,50 & 102,87 \\
Retribusi Perizinan Tertentu & $\mathbf{1 2 4 , 4 3}$ & $\mathbf{2 6 4 , 5 3}$ & $\mathbf{1 0 1 , 7 9}$ & $\mathbf{1 6 3 , 5 8}$ \\
Retribusi Izin Usaha Perikanan : & 135,63 & 246,57 & 106,61 & 162,93 \\
Retribusi Izin Trayek Kepada Orang Pribadi & 90,00 & 163,33 & 0,00 & 84,44 \\
Retribsi Izin mendirikan Bangunan (IMB) & 84,37 & 110,83 & 63,25 & 86,15 \\
$\quad$ Rerata & $\mathbf{1 0 8 , 3 0}$ & $\mathbf{2 0 2 , 7 5}$ & $\mathbf{9 4 , 1 6}$ & $\mathbf{1 3 5 , 0 7}$ \\
\hline Sumber: Data
\end{tabular}

Sumber: Data diolah dari DPPKA Kabupaten Banggai Laut, 2020

Dari Tabel 3 pula dapat dikatakan bahwa rerata realisasi jenis retribusi perizinan tertentu tertingi yaitu retribusi izin usaha perikanan sebesar 162,93 persen dan terendah retribusi izin trayek kepada orang pribadi sebesar 84,44 persen. Untuk tahun 2017 realisasi 
jenis retribusi perizinan tertentu tertinggi yaitu retribusi izin usaha perikanan sebesar 135,63 persen dan terendah retribusi izin mendirikan bangunan sebesar 84,37 persen, tahun 2018 realisasi jenis retribusi perizinan tertentu tertinggi yaitu retribusi izin usaha perikanan sebesar 246,57 persen dan terendah retribusi izin mendirikan bangunan sebesar 110,83 persen, dan tahun 2019 realisasi jenis retribusi perizinan tertentu tertinggi yaitu retribusi izin usaha perikanan sebesar 106,61 persen dan terendah retribusi izin trayek kepada orang pribadi sebesar 0 persen. Ringkasnya, mayoritas realisasi retribusi daerah dari elemen retribusi daerah melewati target yang telah disepakati.

Tabel 8 di bawah ini tercantum persentase tingkat perkembangan retribusi daerah Kabupaten Banggai Laut tahun 2017-2019. Tabel tersebut disebutkan bahwa tingkat perkembangan jenis retribusi daerah rerata sebesar 16,08 persen, rerata tertinggi yaitu retribusi jasa umum, disusul retribusi perizinan tertentu sebesar 19,62 persen dan terendah retribusi jasa usaha sebesar 3,64 persen. Kemudian, tingkat perkembangan jenis retribusi daerah tahun 2017, yaitu tertinggi retribusi perizinan tertentu sebesar 33,06 persen, disusul retribusi jasa usaha sebesar 28,5 persen, dan terendah retribusi jasa umum sebesar 0,54 persen, tahun 2018 tertinggi retribusi perizinan tertentu sebesar 40,61 persen, diikuti retribusi jasa umum sebesar 8,69 persen, dan terendah -1,39 persen, dan tahun 2019 tertinggi yaitu retribusi jasa umum sebesar 24,99 persen, disusul retribusi perizinan tertentu sebesar 19,62 persen, dan terendah retribusi jasa usaha sebesar 3,64 persen. Persentase dalam tabel tersebut mengisyaratkan bahwa secara umum tingkat perkembangan jenis retribusi daerah masih dibawah angka 20 persen.

Tabel 8. Persentase Tingkat Perkembangan Jenis Retribusi Daerah Kabupaten Banggai Laut Tahun 2017-2019

\begin{tabular}{lrrrr}
\multicolumn{1}{c}{ Jenis Retribusi Dae rah } & \multicolumn{4}{c}{ Tahun } \\
& $\mathbf{2 0 1 7}$ & $\mathbf{2 0 1 8}$ & $\mathbf{2 0 1 9}$ & Re rata \\
\hline Retribusi Jasa Umum & $\mathbf{0 , 5 4}$ & $\mathbf{8 , 6 9}$ & $\mathbf{6 5 , 7 4}$ & $\mathbf{2 4 , 9 9}$ \\
Retribusi Pelayanan Parkir ditepi Jalan Umum & $-71,69$ & 57,20 & 16,66 & 0,72 \\
Retribusi Pengujian Kendaraan Bermotor & $-15,26$ & 91,20 & $-100,00$ & $-8,02$ \\
Retribusi Pelayanan Persampahan/ Kebersihan & 54,12 & 2,81 & 26,43 & 27,79 \\
Retribusi Pelayanan Pasar & 34,00 & $-10,03$ & 40,87 & 21,61 \\
Retribusi Pelayanan Kesehatan & $-0,68$ & 9,36 & 68,41 & 25,70 \\
Retribusi Jasa Usaha & $\mathbf{2 8 , 5 0}$ & $\mathbf{- 1 , 3 9}$ & $\mathbf{- 1 6 , 1 8}$ & $\mathbf{3 , 6 4}$ \\
Retribusi Pemakaian Kekayaan Daerah & 19,99 & 1,50 & $-20,03$ & 0,49 \\
Retribusi Terminal & 84,47 & $-23,55$ & $-28,55$ & 10,79 \\
Retribusi Pelayanan Jasa Kepelabuhanan & 7,75 & 12,92 & $-1,48$ & 6,40 \\
Rumah Potong Hewan & 0,00 & 11,22 & 8,39 & 6,54 \\
Retribusi Perizinan Tertentu & $\mathbf{3 3 , 0 6}$ & $\mathbf{4 0 , 6 1}$ & $\mathbf{- 1 4 , 8 1}$ & $\mathbf{1 9 , 6 2}$ \\
Retribusi Izin Usaha Perikanan & 51,64 & 43,02 & $-11,22$ & 27,81 \\
Retribusi Izin Trayek Kepada Orang Pribadi & 6,51 & 81,48 & $-100,00$ & $-4,00$ \\
Retribsi Izin mendirikan Bangunan (IMB) & $-7,20$ & 77,35 & $-42,93$ & 9,07 \\
$\quad$ Re rata & $\mathbf{2 0 , 7 0}$ & $\mathbf{1 5 , 9 7}$ & $\mathbf{1 1 , 5 8}$ & $\mathbf{1 6 , 0 8}$ \\
\hline
\end{tabular}

Sumber: Data diolah dari DPPKA Kabupaten Banggai Laut, 2020

Lebih lanjut, pada Tabel 8 tersebut dapat pula dilihat bahwa tingkat perkembangan retribusi daerah untuk kelompok retribusi jasa umum rerata tertinggi yaitu retribusi pelayanan persampahan/kebersihan sebesar 27,79 persen dan terendah retribusi pengujian kendaraan bermotor sebesar $-8,02$ persen. Tingkat perkembangan retribusi daerah untuk kelompok 
retribusi jasa umum, tahun 2017 tertinggi retribusi pelayanan persampahan/kebersihan sebesar 54,12 persen dan terendah retribusi pelayanan parkir ditepi jalan umum sebesar 71,69 persen, tahun 2018 tertinggi retribusi pengujian kendaraan bermotor sebesar 91,2 persen dan terendah retribusi pelayanan pasar sebesar -10,03 persen, dan tahun 2019 tertinggi retribusi pelayanan kesehatan sebesar 68,41 persen dan terendah retribusi pengujian kendaraan bermotor -100 persen. Kemudian, tingkat perkembangan retribusi daerah untuk kelompok retribusi jasa usaha rerata tertinggi yaitu retribusi terminal sebesar 10,79 persen dan terendah retribusi pemakaian kekayaan daerah sebesar 0,49 persen. Tingkat perkembangan retribusi daerah untuk kelompok retribusi jasa usaha, tahun 2017 tertinggi retribusi terminal sebesar 84,47 persen dan terendah rumah potong hewan sebesar 0 persen, tahun 2018 tertinggi retribusi pelayanan jasa kepelabuhanan sebesar 12,92 persen dan terendah retribusi terminal sebesar $-23,55$ persen, dan tahun 2019 tertinggi rumah potong hewan sebesar 8,39 persen dan terendah retribusi terminal -28,55 persen. Sementara itu, tingkat perkembangan retribusi daerah untuk kelompok retribusi perizinan tertentu rerata tertinggi yaitu retribusi izin usaha perikanan sebesar 27,81 persen dan terendah retribusi izin trayek kepada orang pribadai sebesar -4 persen. Tingkat perkembangan retribusi daerah untuk kelompok retribusi perizinan tertentu, tahun 2017 tertinggi retribusi izin usaha perikanan sebesar 51,64 persen dan terendah retribusi retribusi izin mendirikan bangunan sebesar -7,2 persen, tahun 2018 tertinggi retribusi izin trayek kepada orang pribadi sebesar 81,48 persen dan terendah retribusi izin usaha perikanan sebesar 43,02 persen, dan tahun 2019 tertinggi retribusi izin usaha perikanan sebesar $-11,22$ persen dan terendah retribusi izin trayek kepada orang pribadi sebesar -100 persen.

Tabel 9. Persentase Tingkat Kontribusi Jenis Retribusi Daerah Kabupaten Banggai Laut Tahun 2017-2019

\begin{tabular}{lrrrr}
\multicolumn{1}{c}{ Jenis Retribusi Dae rah } & \multicolumn{4}{c}{ Tahun } \\
& $\mathbf{2 0 1 7}$ & $\mathbf{2 0 1 8}$ & $\mathbf{2 0 1 9}$ & Rerata \\
\hline Retribusi Jas a Umum & $\mathbf{8 0 , 4 0}$ & $\mathbf{7 7 , 4 7}$ & $\mathbf{8 7 , 0 3}$ & $\mathbf{8 1 , 6 3}$ \\
Retribusi Pelayanan Parkir ditepi Jalan Umum & 0,25 & 0,34 & 0,27 & 0,29 \\
Retribusi Pengujian Kendaraan Bermotor & 0,12 & 0,20 & 0,00 & 0,11 \\
Retribusi Pelayanan Persampahan/ Kebersihan & 2,29 & 2,08 & 1,79 & 2,05 \\
Retribusi Pelayanan Pasar & 3,09 & 2,47 & 2,36 & 2,64 \\
Retribusi Pelayanan Kesehatan & 74,65 & 72,37 & 82,62 & 76,55 \\
Retribusi Jas a Usaha & $\mathbf{5 , 1 0}$ & $\mathbf{4 , 4 5}$ & $\mathbf{2 , 5 3}$ & $\mathbf{4 , 0 3}$ \\
Retribusi Pemakaian Kekayaan Daerah & 2,70 & 2,42 & 1,31 & 2,14 \\
Retribusi Terminal & 1,15 & 0,78 & 0,38 & 0,77 \\
Retribusi Pelayanan Jasa Kepelabuhanan & 1,18 & 1,18 & 0,79 & 1,05 \\
Rumah Potong Hewan & 0,07 & 0,07 & 0,05 & 0,06 \\
Retribusi Pe rizinan Tertentu & $\mathbf{1 4 , 5 1}$ & $\mathbf{1 8 , 0 8}$ & $\mathbf{1 0 , 4 4}$ & $\mathbf{1 4 , 3 4}$ \\
Retribusi Izin Usaha Perikanan & 12,74 & 16,15 & 9,72 & 12,87 \\
Retribusi Izin Trayek Kepada Orang Pribadi & 0,04 & 0,07 & 0,00 & 0,04 \\
Retribsi Izin mendirikan Bangunan (IMB) & 1,19 & 1,86 & 0,72 & 1,26 \\
\hline Sumbin
\end{tabular}

Sumber: Data diolah dari DPPKA Kabupaten Banggai Laut, 2020

Selanjutnya, Tabel 9 mencatat persentase tingkat kontribusi jenis retribusi daerah terhadap retribusi daerah di Kabupaten Banggai Laut tahun 2017-2019. Tabel tersebut menginformasikan bahwa tingkat kontribusi tertinggi adalah kelompok retribusi jasa umum sebesar 81,63 persen, disusul retribusi perizinan tertentu sebesar 14,34 persen dan terendah retribusi jasa usaha sebesar 4,03 persen. Lebih lanjut, tingkat kontribusi jenis retribusi daerah 
kelompok retribusi jasa umum rerata tertinggi yaitu retribusi jasa umum sebesar 80,40 persen tahun 2017, sebesar 77,47 persen tahun 2018, dan sebesar 87,03 persen tahun 2019. Tingkat kontribusi retribusi perizinan tertentu yaitu pada tahun 2017 sebesar 14,51 persen, tahun 2018 sebesar 18,08 persen, dan tahun 2019 sebesar 10,44 persen, dan terendah retribusi jasa usaha sebesar 5,1 persen tahun 2017, sebesar 4,45 persen tahun 2018, dan sebesar 2,53 persen tahun 2019. Artinya, angka ini menyampaikan bahwa penerimaan retribusi daerah didominasi dari kelompok retribusi jasa umum.

Dari Tabel 9 tersebut juga dapat dilihat tingkat kontribusi jenis retribusi daerah untuk kelompok retribusi jasa umum, rerata tertinggi yaitu retribusi pelayanan kesehatan sebesar 76,55 persen dan terendah retribusi pengujian kendaraan bermotor sebesar 0,11 persen. Lebih detail, tingkat kontribusi tertinggi yaitu retribusi pelayanan kesehatan sebesar 74,65 persen tahun 2017, sebesar 72,37 persen tahun 2018, dan sebesar 82,62 persen tahun 2019. Kemudian, tingkat kontribusi terendah yaitu retribusi pengujian kendaraan bermotor pada tahun 2017 sebesar 0,12 persen, tahun 2018 sebesar 0,2 persen, dan tahun 2019 sebesar 0 persen. Merujuk tabel 9 pula menyajikan persentase tingkat kontribusi retribusi daerah kelompok retribusi jasa usaha rerata tertinggi yaitu retribusi pemakaian kekayaan daerah sebesar 2,14 persen dan terendah retribusi rumah potong hewan sebesar 0,06 persen. Tingkat kontribusi tertinggi yaitu retribusi pemakaian kekayaan daerah sebesar 2,7 persen tahun 2017, 2,42 persen tahun 2018, dan 1,31 persen tahun 2019, dan kontribusi terendah yaitu retribusi rumah potong hewan pada tahun 2017 sebesar 0,07 persen, tahun 2018 sebesar 0,07 persen, dan tahun 2019 sebesar 0,05 persen. Tabel 9 pula menampilkan persentase tingkat kontribusi jenis retribusi daerah kelompok retribusi perizinan tertentu, dengan rerata rerata tertinggi yaitu retribusi izin usaha perikanan sebesar 12,87 persen dan terendah retribusi izin trayek kepada orang pribadi sebesar 0,04 persen. Lebih dari itu, realisasi kontribusi tertinggi yaitu retribusi izin usaha perikanan sebesar 12,74 persen tahun 2017, sebesar 16,15 persen tahun 2018, dan sebesar 9,72 persen tahun 2019, dan kontribusi terendah yaitu retribusi izin trayek kepada orang pribadi tahun 2017 sebesar 0,04 persen, tahun 2018 sebesar 0,07 persen, dan tahun 2019 sebesar 0 persen.

\subsection{Pembahasan}

Dua komponen utama PAD, yaitu pajak daerah dan retribusi daerah yang apabila dikelola dengan baik, dianggap dapat memberikan kontribusi terbesar terhadap PAD. Pada tabel 10 menunjukkan kriteria efektivitas realisasi pajak daerah kabupaten Banggai Laut. Dari tabel tersebut tercatat bahwa enam jenis pajak daerah yang realisasinya tergolong dalam kriteria sangat efektif, yaitu pajak hotel, pajak restoran, pajak penerangan jalan rumah tangga, pajak galian batu/ kerikil/ pasir, dan sisanya dua jenis pajak daerah termasuk dalam kriteria realisasi cukup efektif yaitu pajak hiburan dan pajak reklame/ billboard/ seng. Dengan kata lain, efektivitas realisasi jenis pajak daerah secara umum sangat efektif. Hasil ini sejalan dengan penelitian Sucanti et al. (2017) di Kabupaten Gianyar, Utami dan Ningsih (2018) pada kabupaten dan kota di Provinsi Aceh, Tamburaka et al. (2018) di Kabupaten Konawe, yang menjelaskan bahwa tingkat realisasi jenis pajak daerah tergolong dalam kualifikasi sangat efektif. Akan tetapi, agak berbeda dengan temuan Sartika et al. (2019) yang menunjukkan bahwa tingkat efektivitas realisasi pajak daerah kabupaten/kota di Sumatera Barat termasuk dalam kualifikasi efektif.

Kemudian, Tabel 10 pula terlihat bahwa hanya satu jenis pajak daerah yang tingkat perkembannya termasuk dalam kualifikasi berhasil yaitu bea perolehan hak atas tanah dan bangunan, dan hanya pajak bumi dan bangunan perdesaan dan perkotaan tergolong dalam kriteria kurang berhasil. Sementara, enam jenis pajak daerah lainnya termasuk dalam kriteria perkembangan tidak berhasil yaitu pajak hotel, pajak restoran, pajak hiburan, pajak papan reklame/ billboard/ seng, pajak penerangan jalan rumah tangga, dan pajak galian batu/ kerikil/ pasir. Kriteria ini mengisyaratkan bahwa mayoritas perkembangan (pertumbuhan) jenis pajak 
daerah dapat dinyatakan tidak berhasil. Hasil ini sesuai dengan penelitian Syamsul (2019) yang menginformasikan bahwa tingkat perkembangan jenis pajak daerah di Kabupaten Parigi Moutong tergolong rendah (tidak berhasil). Begitupula, penelitian Sartika et al. (2019) pada kabupaten/kota di Sumatera Barat yang juga menemukan bahwa tingkat perkembangan pajak daerah termasuk dalam kulifikasi tidak berhasil.

\begin{tabular}{lcccccc}
$\begin{array}{l}\text { Tabel 10. Kriteria Efektivitas, Perkembangan, dan } \\
\text { Kabupaten Banggai Laut }\end{array}$ & \multicolumn{1}{c}{ Kontribusi } & Jenis Pajak Daerah & Pata \\
\multicolumn{1}{c}{ Jenis Pajak Daerah } & $\begin{array}{c}\text { Rerata } \\
\text { Realisasi }\end{array}$ & Kriteria & $\begin{array}{c}\text { Rerata } \\
\text { Perkembangan }\end{array}$ & Kriteria & $\begin{array}{c}\text { Rerata } \\
\text { Kontribusi }\end{array}$ & Kriteria \\
\hline Pajak Hotel & 131,42 & Sangat Efektif & 28,12 & Tidak Berhasil & 2,05 & Sangat Kurang Baik \\
Pajak Restoran & 117,39 & Sangat Efektif & 17,04 & Tidak Berhasil & 13,00 & Kurang Baik \\
Pajak Hiburan & 86,60 & Cukup Efektif & $-0,93$ & Tidak Berhasil & 0,01 & Sangat Kurang Baik \\
Pajak Papan Reklame/Billboard/ Seng & 80,64 & Cukup Efektif & $-33,79$ & Tidak Berhasil & 0,45 & Sangat Kurang Baik \\
Pajak Penerangan Jalan Rumah Tangga & 117,44 & Sangat Efektif & 20,37 & Tidak Berhasil & 37,96 & Sedang \\
Pajak Galian Batu / Kerikil / Pasir & 100,86 & Sangat Efektif & $-3,98$ & Tidak Berhasil & 25,26 & Cukup Baik \\
PBB Perdesaan dan Perkotaan & 103,78 & Sangat Efektif & 46,57 & Kurang Berhasil & 18,29 & Kurang Baik \\
Bea Perolehan Hak atas Tanah dan Bangunan & 164,08 & Sangat Efektif & 77,66 & Berhasil & 2,97 & Sangat Kurang Baik \\
\hline Sumber: Data diolah dari DPRKA
\end{tabular}

Sumber: Data diolah dari DPPKA Kabupaten Banggai Laut, 2020

Melihat Tabel 10 itu, juga dijelaskan bahwa terdapat empat jenis pajak daerah dengan tingkat kontribusinya terhadap retribusi daerah tergolong dalam kriteria sangat kurang baik, yaitu pajak hotel, pajak hiburan, pajak papan reklame/ billboard/ seng, dan bea perolehan hak atas tanah dan bangunan. Selain itu, ada dua jenis pajak daerah yaitu pajak restoran dan pajak bumi dan bangunan perdesaan dan perkotaan tergolong dalam kriteria kontribusi kurang baik, dan hanya pajak galian batu/ kerikil/ pasir yang termasuk dalam kriteria kontribusi cukup baik, begitu pula hanya pajak penerangan jalan rumah tangga tergolong dalam kriteria kontribusi sedang. Kondisi ini menandakan bahwa sebagian besar jenis pajak daerah, jika dilihat dari tingkat kontribusinya terhadap pajak daerah dapat dikatakan sangat kurang baik. Temuan ini sejalan dengan penelitian Sucanti et al. (2017) di Kabupaten Gianyar dan Syamsul (2019) di Kabupaten Parigi Moutong yang menunjukkan bahwa mayoritas tingkat kontribusi jenis pajak daerah termasuk dalam kualifikasi sangat kurang. Akan tetapi, berbeda dengan temuan Sartika et al. (2019), Tamburaka et al. (2018), dan Utami dan Ningsih (2018) yang menjelaskan bahwa tingkat kontribusi jenis pajak daerah mayoritas termasuk dalam kualifikasi cukup baik dan sedang.

Merujuk pada Tabel 11 disebutkan bahwa terdapat lima jenis retribusi daerah dari kelompok retribusi jasa umum yang tergolong dalam kriteria realisasi sangat efektif, yaitu retribusi pelayanan parkir ditepi jalan umum, retribusi pelayanan persampahan/kebersihan, retribusi pelayanan pasar, dan retribusi pelayanan pasar. Kemudian, hanya retribusi pengujian kendaraan bermotor yang merupakan kelompok dari retribusi jasa umum yang tergolong dalam kriteria realisasi cukup efektif. Lebih lanjut, juga dinyatakan bahwa tercatat dua jenis retribusi daerah dari kelompok retribusi jasa usaha yang tergolong dalam kriteria realisasi sangat efektif, yaitu retribusi pelayanan jasa kepelabuhanan dan retribusi rumah potong hewan, dan hanya retribusi terminal yang termasuk dalam kriteria realisasi efektif, serta hanya retribusi pemakaian kekayaan daerah yang tergolong dalam kriteria realisasi kurang efektif. Selain itu, terdapat dua jenis retribusi daerah dari kelompok retribusi perizinan tertentu termasuk dalam kriteria realisasi cukup efektif yaitu retribusi izin trayek kepada orang pribadi dan retribusi Izin Mendirikan Bangunan (IMB), sedangkan retribusi izin usaha perikanan tergolong dalam kriteria realisasi sangat efektif. Fakta ini mengisyaratkan bahwa mayoritas realisasi jenis retribusi daerah terhitung sangat efektif. Hasil ini sesuai dengan penelitian Sucanti et al. (2017), Tamburaka et al. (2018), dan Utami dan Ningsih (2018) yang juga menemukan tingkat efektivitas realisasi jenis retribusi daerah tergolong dalam 
kualifikasi sangat efektif. Namun sedikit berbeda, dengan temuan Sartika et al. (2019) yang menemukan bahwa tingkat realisasi retribusi daerah lebih rendah sedikit, yaitu tergolong dalam kriteria efektif.

Tabel 11. Kriteria Efektivitas, Perkembangan, dan Kontribusi Jenis Retribusi Daerah Kabupaten Banggai Laut

\begin{tabular}{lcccccc}
\hline \multicolumn{1}{c}{ Jenis Retribusi Dae rah } & $\begin{array}{c}\text { Rerata } \\
\text { Realis asi }\end{array}$ & Kriteria & $\begin{array}{c}\text { Rerata } \\
\text { Perkembangan }\end{array}$ & \multicolumn{2}{c}{ Krite ria } & $\begin{array}{c}\text { Rerata } \\
\text { Kontribusi }\end{array}$ \\
& $\mathbf{1 3 9 , 2 8}$ & Sangat Efektif & $\mathbf{2 4 , 9 9}$ & Tidak Berhasil & $\mathbf{8 1 , 6 3}$ & Sangat Baik \\
Retribusi Jasa Umum & 135,08 & Sangat Efektif & 0,72 & Tidak Berhasil & 0,29 & Sangat Kurang Baik \\
Retribusi Pelayanan Parkir ditepi Jalan Umum & 80,67 & Cukup Efektif & $-8,02$ & Tidak Berhasil & 0,11 & Sangat Kurang Baik \\
Retribusi Pengujian Kendaraan Bermotor & 133,33 & Sangat Efektif & 27,79 & Tidak Berhasil & 2,05 & Sangat Kurang Baik \\
Retribusi Pelayanan Persampahan/ Kebersihan & 168,49 & Sangat Efektif & 21,61 & Tidak Berhasil & 2,64 & Sangat Kurang Baik \\
Retribusi Pelayanan Pasar & 136,98 & Sangat Efektif & 25,70 & Tidak Berhasil & 76,55 & Sangat Baik \\
Retribusi Pelayanan Kesehatan : & $\mathbf{1 0 2 , 3 5}$ & Sangat Efektif & $\mathbf{3 , 6 4}$ & Tidak Berhasil & $\mathbf{4 , 0 3}$ & Sangat Kurang Baik \\
Retribusi Jasa Usaha & 60,73 & Kurang Efektif & 0,49 & Tidak Berhasil & 2,14 & Sangat Kurang Baik \\
Retribusi Pemakaian Kekayaan Daerah & 90,47 & Efektif & 10,79 & Tidak Berhasil & 0,77 & Sangat Kurang Baik \\
Retribusi Terminal & 144,76 & Sangat Efektif & 6,40 & Tidak Berhasil & 1,05 & Sangat Kurang Baik \\
Retribusi Pelayanan Jasa Kepelabuhanan & 102,87 & Sangat Efektif & 6,54 & Tidak Berhasil & 0,06 & Sangat Kurang Baik \\
Rumah Potong Hewan & $\mathbf{1 6 3 , 5 8}$ & Sangat Efektif & $\mathbf{1 9 , 6 2}$ & Tidak Berhasil & $\mathbf{1 4 , 3 4}$ & Kurang Baik \\
Retribusi Perizinan Tertentu & 162,93 & Sangat Efektif & 27,81 & Tidak Berhasil & 12,87 & Kurang Baik \\
Retribusi Izin Usaha Perikanan : & 84,44 & Cukup Efektif & $-4,00$ & Tidak Berhasil & 0,04 & Sangat Kurang Baik \\
Retribusi Izin Trayek Kepada Orang Pribadi & 86,15 & Cukup Efektif & 9,07 & Tidak Berhasil & 1,26 & Sangat Kurang Baik \\
Retribsi Izin mendirikan Bangunan (IMB) & & &
\end{tabular}

Sumber: Data diolah dari DPPKA Kabupaten Banggai Laut, 2020

Pada Tabel 11 juga dijelaskan bahwa semua jenis retribusi daerah dari kelompok retribusi jasa umum tergolong dalam kriteria perkembangan yang tidak berhasil. Begitu pula, jenis retribusi daerah dari kelompok retribusi jasa usaha dan retribusi perizinan tertentu semuanya termasuk dalam kriteria perkembangan tidak berhasil. Artinya, secara keseluruhan perkembangan retribusi daerah dapat dinyatakan tidak berhasil. Temuan ini sejalan dengan penelitian Sartika et al. (2019), dan Syamsul (2019) yang mengindikasikan bahwa tingkat perkembangan retribusi daerah termasuk dalam kualifikasi tidak berhasil.

Selanjutnya, Tabel 11 pula ditunjukkan bahwa hanya satu jenis retribusi daerah dari kelompok retribusi jasa umum, yaitu retribusi pelayanan kesehatan termasuk dalam kriteria kontribusi sangat baik. Lebihnya, tergolong dalam kriteria kontribusi sangat kurang baik, diantaranya retribusi pelayanan parkir ditepi jalan umum, retribusi pengujian kendaraan bermotor, retribusi pelayanan persampahan/kebersihan, dan rertibusi pelayanan pasar. Kemudian, jenis retribusi daerah dari kelompok retribusi jasa usaha semuanya termasuk dalam kriteria kontribusi sangat kurang baik, yaitu retribusi pemakaian kekayaan daerah, retribusi terminal, retribusi pelayanan jasa kepelabuhanan, dan retribusi rumah potong hewan. Selain itu, juga terlihat bahwa terdapat satu jenis retribusi daerah dari kelompok retribusi perizinan tertentu yang termasuk dalam kriteria kurang baik yaitu retribusi izin usaha perikanan, dan dua jenis retribusi lainnya dari kelompok ini tergolong dalam kriteria kontribusi sangat kurang baik yaitu retribusi izin trayek kepada orang pribadi dan retribusi izin mendirikan bangunan (IMB). Sederhananya, kontribusi jenis retribusi daerah terbilang sangat kurang baik. Hasil ini serupa dengan penelitian Sucanti et al. (2017), Syamsul (2019), dan Utami dan Ningsih (2018), tetapi berbeda dengan temuan Ersita dan Elim (2016), Rosa et al. (2020), Tamburaka et al. (2018), dan Yoduke dan Ayem (2015) yang menemukan mayoritas tingkat kontribusi retribusi daerah termasuk dalam kualifikasi cukup dan sedang. 
Tabel 12. Matriks Perkembangan dan Kontribusi Jenis Pajak Daerah Kabupaten Banggai Laut

\begin{tabular}{|c|c|c|c|c|}
\hline \multicolumn{5}{|c|}{ Kategori } \\
\hline & Prima & Potensial & Berkembang & Terbelakang \\
\hline $\begin{array}{c}\text { Jenis } \\
\text { Pajak } \\
\text { Daerah }\end{array}$ & $\begin{array}{ll}\text { - } & \text { Pajak Hotel } \\
\text { - } & \text { Pajak Restoran } \\
\text { - } & \text { Pajak Penerangan } \\
& \text { Jalan Rumah } \\
& \text { Tangga } \\
\text { - } & \text { PBB Perdesaan } \\
& \text { dan Perkotaan } \\
\text { - } & \text { Bea Perolehan } \\
& \text { Hak atas Tanah } \\
\text { dan Bangunan }\end{array}$ & & $\begin{array}{l}\text { - } \text { Pajak Galian } \\
\text { Batu / } \\
\text { Kerikil / } \\
\text { Pasir }\end{array}$ & $\begin{array}{ll}\text { - } & \text { Pajak Hiburan } \\
\text { - } & \text { Pajak Papan } \\
& \text { Reklame/Billboa } \\
\text { rd/Seng }\end{array}$ \\
\hline
\end{tabular}

Sumber: Data diolah dari DPPKA Kabupaten Banggai Laut, 2020

Tabel 12 di atas ini merupakan matriks perkembangan dan kontribusi jenis pajak daerah Kabupaten Banggai Laut. Dari analisis overlay pada Tabel 8 tersebut, tertera bahwa yang terdapat lima jenis pajak daerah yang termasuk dalam kualifikasi prima yaitu pajak hotel, pajak restoran, pajak penerangan jalan rumah tangga, pajak bumi dan bangunan perdesaan dan perkotaan, bea perolehan hak atas tanah dan bangunan. Selain itu, dari tabel tersebut juga terlihat bahwa tidak terdapat jenis pajak daerah yang termasuk dalam kualifikasi potensial, kemudian hanya satu jenis pajak daerah yang termasuk dalam kualifikasi berkembang yaitu pajak galian batu/krikil/pasir, dan terdapat dua jenis pajak yang masih tergolong terbelakang yaitu pajak hiburan dan pajak papan reklame/ billboard/ seng. Oleh karena itu, mayoritas jenis pajak daerah Kabupaten Banggai Laut tergolong dalam kualifikasi prima. Hasil ini pararel dengan analisis Syamsul (2019) yang menunjukkan tingkat perkembangan dan kontribusi jenis pajak daerah Kabupaten Parigi Moutong termasuk dalam kualifikasi prima. Artinya, melalui analisis overlay ini ditunjukkan bahwa tidak terdapat perbedaan antara tingkat perkembangan dan kontribusi jenis pajak daerah antara Kabupaten Banggai Laut dan Kabupaten Parigi Moutong.

Tabel 13. Matriks Perkembangan dan Kontribusi Jenis Retribusi Daerah Kabupaten Banggai Laut

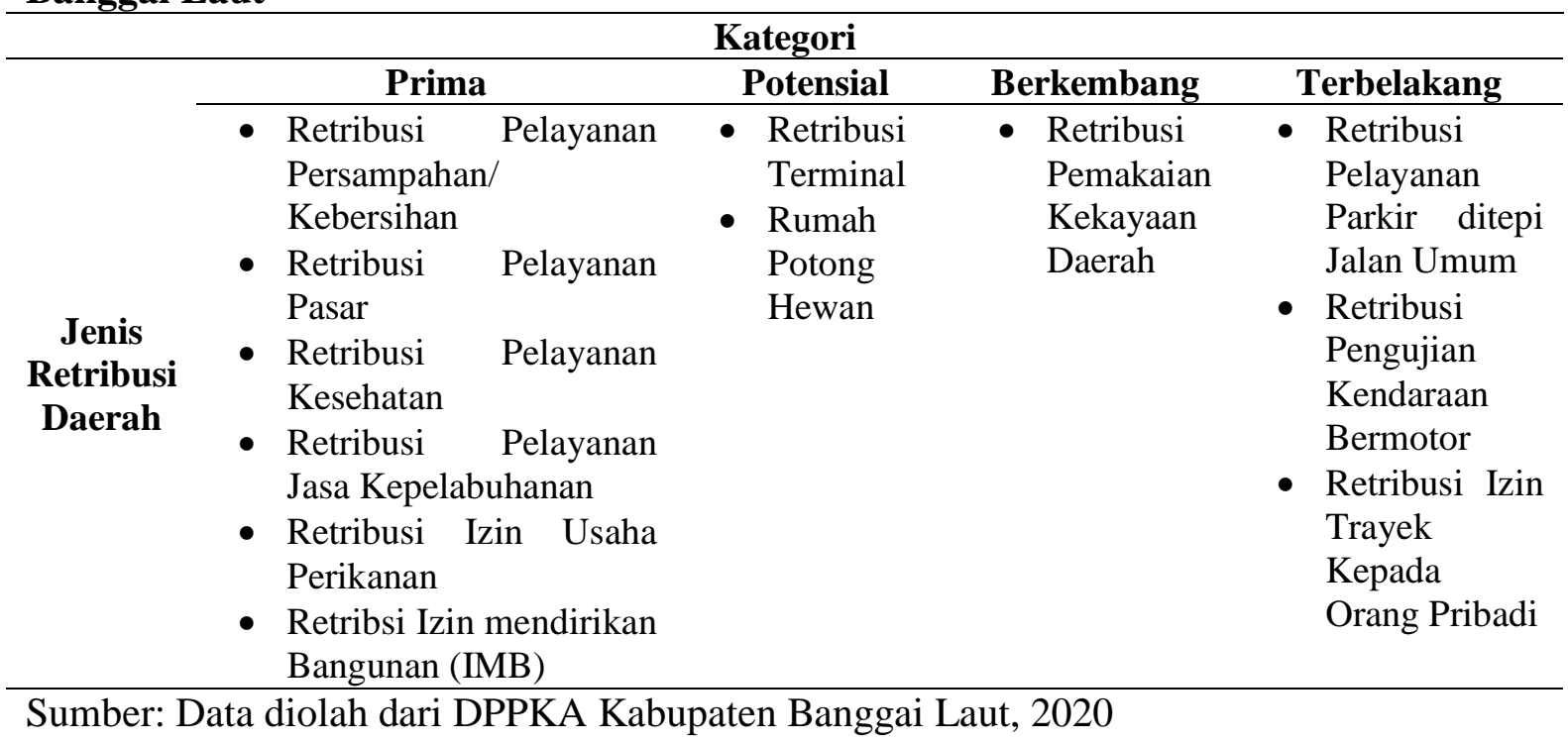


Tabel 13 menampilkan matriks perkembangan dan kontribusi jenis retribusi daerah Kabupaten Banggai Laut. Melalui analisis overlay pada tabel tersebut, dapat dijelaskan bahwa terdapat enam jenis retribusi daerah yang termasuk dalam kualifikasi prima yaitu retribusi pelayanan persampahan/kebersihan, retribusi pelayanan pasar, retribusi pelayanan kesehatan, retribusi pelayanan jasa kepelabuhanan, retribusi izin usaha perikanan, dan retribusi izin mendirikan bangunan (IMB). Sementara itu, retribusi terminal dan retribusi rumah potong hewan tergolong dalam kualifikasi potensial, dan retribusi pemakaian kekayaan daerah termasuk dalam kualifikasi berkembang. Selanjutnya, terdapat tiga jenis retribusi daerah yang termasuk dalam kualifikasi terbelakang yaitu retribusi pelayanan parkir ditepi jalam umum, retribusi pengujian kendaraan bermotor, dan retribusi izin trayek kepada orang pribadi. Oleh karena itu, dapat dikatakan bahwa hanya sebagian jenis retribusi daerah yang termasuk dalam kualifikasi prima dan potensial. Hasil ini bertolak belakang dengan penelitian Syamsul (2019) yang menginformasikan tingkat perkembangan dan kontribusi jenis pajak daerah termasuk dalam kualifikasi berkembang dan terbelakang. Artinya, tingkat perkembangan dan kontribusi jenis pajak daerah Kabupaten Banggai Laut lebih tinggi dibanding Kabupaten Parigi Moutong.

\section{KESIMPULAN DAN SARAN}

\subsection{Kesimpulan}

Penelitian ini membahas terkait tingkat efektivitas, perkembangan, dan kontribusi pajak daerah dan retribusi daerah Kabupaten Banggai Laut tahun 2016-2019. Hasil analisis menunjukkan bahwa rerata efektivitas penerimaan jenis pajak daerah sebesar 112,77 persen, kemudian rerata tingkat perkembangannya sebesar 18,88 persen, dan tingkat kontribusinya terhadap PAD yaitu kurang dari 30,00 persen. Sementara itu, rerata tingkat efektivitas realisasi jenis retribusi daerah adalah sebesar 135,07 persen, rerata tingkat perkembangannya sebesar 16,08 persen, dan tingkat kontribusinya terhadap PAD yaitu kurang dari 20,00 persen.

Selanjutnya, kategori tingkat efektivitas realisasi jenis pajak daerah mayoritas termasuk dalam kualifikasi sangat efektif, tetapi tingkat perkembangannya termasuk mayoritas termasuk dalam kualifikasi tidak berhasil, begitu pula tingkat kontribusinya terhadap PAD sebagian besar terbilang masih sangat kurang baik. Kemudian, kategori tingkat realisasi retribusi daerah mayoritas tergolong dalam kualifikasi sangat efektif, sementara tingkat perkembangannya sebagian besar termasuk dalam kualifikasi tidak berhasil, dan tingkat kontribusinya juga sebagian besar masih termasuk dalam kualifikasi sangat kurang baik.

Terakhir, melalui analisis overlay ditemukan bahwa mayoritas jenis pajak daerah termasuk dalam kualifikasi prima, yaitu pajak hotel, pajak restoran, pajak penerangan jalan rumah tangga, pajak bumi dan bangunan perdesaan dan perkotaan, bea perolehan hak atas tanah dan bangunan. Sementara itu, terdapat enam jenis retribusi daerah yang tergolong dalam kualifikasi prima yaitu retribusi pelayanan persampahan/kebersihan, retribusi pelayanan pasar, retribusi pelayanan kesehatan, retribusi pelayanan jasa kepelabuhanan, retribusi izin usaha perikanan, dan retribusi Izin Mendirikan Bangunan (IMB).

\subsection{Saran}

Melalui analisis pada penelitian ini, direkomendasikan kepada pemerintah daerah terkait, untuk jenis pajak daerah maupun retribusi daerah yang termasuk dalam kualifikasi berkembang dan terbelakang dijadikan prioritas utama dikembangkan. Selain itu, diharapkan di masa mendatang, realisasi pajak daerah dan retribusi daerah Kabupaten Banggai Laut dapat ditingkatkan lagi melalui upaya pemungutan yang optimal (maksimal) dan disertai dengan pengawasan yang ketat. Saran untuk penelitian selanjutnya, yaitu lebih menggali 
strategi-strategi dalam meningkatkan perkembangan dan kontribusi dari setiap jenis pajak daerah dan retribusi daerah.

\section{DAFTAR PUSTAKA}

Ersita, M., \& Elim, I. (2016). Analisis efektivitas penerimaan retribusi daerah dan kontribusinya terhadap peningkatan Pendapatan Asli Daerah (PAD) di Provinsi Sulawesi Utara. Jurnal Riset Ekonomi, Manajemen, Bisnis dan Akuntansi, 4(1), 889897. https://ejournal.unsrat.ac.id/index.php/emba/article/view/11818

Gunawan, E. (2018). Pengaruh efektivitas penerimaan pajak daerah dan retribusi daerah terhadap pendapatan asli daerah Kabupaten Aceh Timur. Jurnal Ekonomi Manajemen $\begin{array}{llll}\text { Teknologi } \quad \text { KITA, 28-37. } & \end{array}$ http://www.journal.lembagakita.org/index.php/emt/article/view/52

Halim, A. (2007). Akuntansi sektor publik: Akuntansi keuangan daerah (3rd ed.). Jakarta: Salemba Empat.

Jaya, M. K. (1996). Analisis keuangan daerah: Pendekatan makro, model program PMSES. Laporan Penelitian. Kerjasama Ditjrn PUOD Depdagri dengan Pusat Penelitian dan Pengkajian Ekonomi dan Bisnis, UGM, Yogyakarta.

Kamaroellah, R. A. (2017). Analisis tingkat kemampuan keuangan daerah dalam mendukung pelaksanaan otonomi daerah. NUANSA: Jurnal Penelitian Ilmu Sosial dan Keagamaan Islam, 14(1), 123-138. http://ejournal.iainmadura.ac.id/nuansa/article/view/1316

Kurniawan, A. (2019). Analisis pengelolaan retribusi daerah sebagai strategi peningkatan Pendapatan Asli Daerah (PAD): Studi kasus pada seluruh Organisasi Perangkat Daerah (OPD) terkait retribusi di Kabupaten Tulungagung. Jurnal Ilmiah Administrasi Publik, 5(1), 87-96. https://doi.org/10.21776/ub.jiap.2019.005.01.11

Mardiasmo. (2004). Otonomi dan manajemen keuangan daerah. Yogyakarta: Penerbit Andi.

Mizkan, H., Kamaliah, \& Agusti, R. (2015). Analisis kinerja pengelolaan keuangan daerah dan pengaruhnya terhadap tingkat kemiskinan di Kota Pekanbaru. SOROT: Jurnal Ilmu-ilmu Sosial, 10(1), 114-130. https://sorot.ejournal.unri.ac.id/index.php/JS/article/view/3209

Ngangi, I. A., Murni, S., \& Untu, N. V. (2018). Analisis kinerja keuangan Pemerintah Kabupaten Sorong Selatan. Jurnal Riset Ekonomi, Manajemen, Bisnis dan Akuntansi, 6(4), 4103-4112. https://ejournal.unsrat.ac.id/index.php/emba/article/view/22227

Nopyandri. (2015). Implikasi berlakunya Undang-Undang Nomor 28 Tahun 2009 tentang Pajak Daerah dan Retribusi Daerah bagi penyelenggaraan pemerintahan daerah. Jurnal Ilmu Hukum, 5(1), 1-13. https://jih.ejournal.unri.ac.id/index.php/JIH/article/view/2777

Rosa, Y. D., Sovita, I., \& Abdilla, M. (2020). Analisis efektifitas dan efisiensi pajak daerah, retribusi daerah dan kontribusinya terhadap Pendapatan Asli Daerah Kota Bukittinggi. Jurnal Ekonomi dan Bisnis Dharma Andalas, 22(2), 358-369. www.jurnal.unidha.ac.id/index.php/JEBD/article/view/141

Sambodo, B., \& Putri, F. R. (2020). Optimalisasi penerimaan pajak daerah dan retribusi untuk meningkatkan Pendapatan Asli Daerah ( PAD ) Kota Tanjungpinang Provinsi Kepulauan Riau. Jurnal Wahana Bhkati Praja, 10(1), 205-210. https://doi.org/10.33701/jiwbp.v10i1.758

Sartika, D., Ulfa, A., \& Ilyas, A. (2019). Analisis potensi penerimaan pajak daerah dan retribusi daerah terhadap Pendapatan Asli Daerah (PAD) Kabupaten/Kota di Provinsi 
Sumatera Barat. Jurnal Ekonomi dan Bisnis Dharma Andalas, 21(1), 32-53. http://jurnal.unidha.ac.id/index.php/JEBD/article/view/14

Sucanti, N. W. A., Kurniawan, P. S., \& Purnamawati, I. G. A. (2017). Studi analisis efektivitas, efisiensi dan kontribusi penerimaan pajak daerah dan retribusi daerah terhadap Pendapatan Asli Daerah (PAD): Studi kasus di Pemerintah Kabupaten Gianyar. E-Journal Universitas Pendidikan Ganesha, 8(2), 1-11. https://ejournal.undiksha.ac.id/index.php/S1ak/article/view/14992

Syamsul. (2020). Evaluasi Pendapatan Asli Daerah (PAD) Kabupaten/Kota di Provinsi Sulawesi Tengah Tahun 2014-2018. Berkala Akuntansi dan Keuangan Indonesia, 5(1), 47-66. https://doi.org/10.20473/baki.v5i1.17937

Syamsul, S. (2019). Pajak daerah dan retribusi daerah Pemerintah Kabupaten Parigi Moutong: Sebuah analisis. Akuntabilitas, 13(2), 109-126. https://doi.org/10.29259/ja.v13i2.9643

Tamburaka, S., Hasbuddin, \& Pina, A. (2018). Evaluasi penerimaan pajak daerah sebagai elemen pendapatan asli daerah Kabupaten Konawe. Jurnal Akuntansi dan Keuangan, 3(1), 99-109. http://ojs.uho.ac.id/index.php/jak-uho/article/view/3780

Utami, M., \& Ningsih, E. S. (2018). Analisis efektivitas dan kontribusi penerimaan pajak dan retribusi daerah terhadap pendapatan asli daerah Kabupaten/Kota di Provinsi Aceh tahun 2011-2015. Jurnal Ilmiah Mahasiswa Ekonomi Akuntansi (JIMEKA), 3(4), 672687. http://www.jim.unsyiah.ac.id/EKA/article/view/10687

Yoduke, R., \& Ayem, S. (2015). Analisis efektivitas, efisiensi pajak daerah dan retribusi daerah serta kontribusi terhadap Pendapatan Asli Daerah di Kabupaten Bantul tahun 2009-2014. Jurnal Akuntansi, 3(2), 28-47. https://doi.org/10.24964/ja.v3i2.49 